\title{
Ab Initio Calculation of the Interaction of an Edge Dislocation with Transition Metal Impurity Atoms in Silicon
}

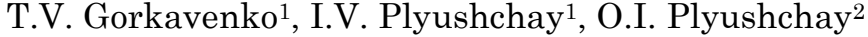 \\ 1 Taras Shevchenko National University of Kyiv, 64/13, Volodymyrska St., 01601 Kyiv, Ukraine \\ ${ }^{2}$ G.V. Kurdyumov Institute for Metal Physics of the N.A.S. of Ukraine, \\ 36, Academician Vernadsky Boulevard, 03142 Kyiv, Ukraine
}

(Received 23 March 2020; revised manuscript received 15 October 2020; published online 25 October 2020)

\begin{abstract}
The first-principle calculation of the interaction of an edge dislocation with transition metal impurities $\mathrm{Cr}, \mathrm{Mn}, \mathrm{Fe}, \mathrm{Co}, \mathrm{Ni}$ and $\mathrm{Cu}$ in a supercell composed of $180 \mathrm{Si}$ atoms is presented. The density functional theory in the general gradient approximation using the ABINIT software package has been used for numerical calculation. The interaction curves of edge dislocations with impurity atoms in silicon are obtained. The shape of the interaction curves corresponds to the Lennard-Jones potential. The equilibrium positions of impurity atoms in the vicinity of the edge dislocation cores are obtained. The binding energy of Cr, $\mathrm{Mn}$, $\mathrm{Fe}, \mathrm{Co}, \mathrm{Ni}, \mathrm{Cu}$ impurity atoms with an edge dislocation in silicon is calculated and analyzed. The electronic structure of the supercell with a dipole of two edge dislocations with $\mathrm{Cr}, \mathrm{Mn}, \mathrm{Fe}, \mathrm{Co}, \mathrm{Ni}$ and $\mathrm{Cu}$ impurities is presented. The general features of the electronic spectra for all impurity atoms are discussed. Due to the existing defective structure of the supercell, additional states appear in the band gap for all impurities, in particular, for $\mathrm{Ni}$ and $\mathrm{Cu}$ impurities, a sharp half-filled impurity peak is observed in the band gap. The intensity and fine structure of impurity peaks vary depending on the type of impurity and its position. The possibility of magnetic ordering on the dislocation core dangling bonds and $\mathrm{Ni}, \mathrm{Cu}$ impurity atoms in the vicinity of the edge dislocation core has been discussed.
\end{abstract}

Keywords: Silicon, Edge dislocation, Transition metals, Electronic structure, Magnetic ordering.

\section{INTRODUCTION}

Transition metal impurities in silicon are technologically important since it is difficult to avoid their presence in silicon and their interaction with free charge carriers may influence electronic devices. Impurities of transition metals are present in the silicon source stuff and are often further introduced during ingot growth and materials processing. These impurities are extremely detrimental in silicon due to their high generation-recombination activity and their ability to form precipitates. For example, transition metal impurities form deep-level recombination centers that deteriorate solar-cell performance [1].

Due to high diffusivity of transition metals, they can easily diffuse through the wafer to the devices. The devices contain heavily doped $n$-type and $p$-type areas, may include areas with high lattice strain, and therefore can provide efficient traps for transition metals via relaxation or segregation mechanisms. Dissolved transition metal point defects or metal-silicide precipitates may segregate to the dislocation strain field and/or bind to the dislocation core, creating additional energy barriers to gettering [2].

Transition metal atoms are supposed to be rather strongly bound to a dislocation strain field or even the dislocation core. Previously this strong binding and the effect on the electrical defect levels have indeed been illustrated for intrinsic defects such as vacancies and self-interstitial clusters in silicon [3] by means of density functional based methods.

It was also shown that the grains of as-grown multicrystalline silicon with low initial diffusion lengths contained high density of agglomerates of $\mathrm{Fe}, \mathrm{Cr}$ and Co [4]. Agglomerates of metals were found both on dislocations and in virtually dislocation-free regions. The impurities precipitated at extended defects introduce deep levels in the band gap and act as recombination centers for minority carriers. Numerous experimental data [5] confirmed the increase in recombination activity of boundaries and dislocations after transition metal contamination. In [6], it was shown that both $\mathrm{Cu}$ and $\mathrm{Ni}$ precipitates give rise to a band-like state in the band gap. The width of the band depends on the size of the precipitates. But the nature of the band-like states is not clear yet.

Therefore, the theoretical study of the peculiarities of transition metals influence on the electronic structure of dislocation silicon is an actual task.

\section{CALCULATION RESULTS AND DISCUSSION}

In this work, we studied the interaction of edge dislocations with transition metals $\mathrm{Cr}, \mathrm{Mn}, \mathrm{Fe}, \mathrm{Co}, \mathrm{Ni}, \mathrm{Cu}$ in silicon. The supercell of 180 silicon atoms with a dipole of two edge dislocations was built. The impurity atoms were placed in the region of the dislocation core, one impurity in each core. A detailed description of how the supercell was built is contained in [7]. Then the impurities moved perpendicular to the dislocation line. $\mathrm{Ab}$ initio calculations of the total energy and the electronic structure of this supercell were performed for each impurity position. The calculations were based on the density functional theory in the general gradient approximation using the ABINIT software package [8].

Fig. 1 shows the interaction curves of the impurity atoms $\mathrm{Cr}, \mathrm{Mn}, \mathrm{Fe}, \mathrm{Co}, \mathrm{Ni}$ and $\mathrm{Cu}$ with an edge dislocation in silicon. Generally, the interaction curves correspond to the well-known Lennard-Jones pair interaction potential, which indicates the adequacy of our calculations. 


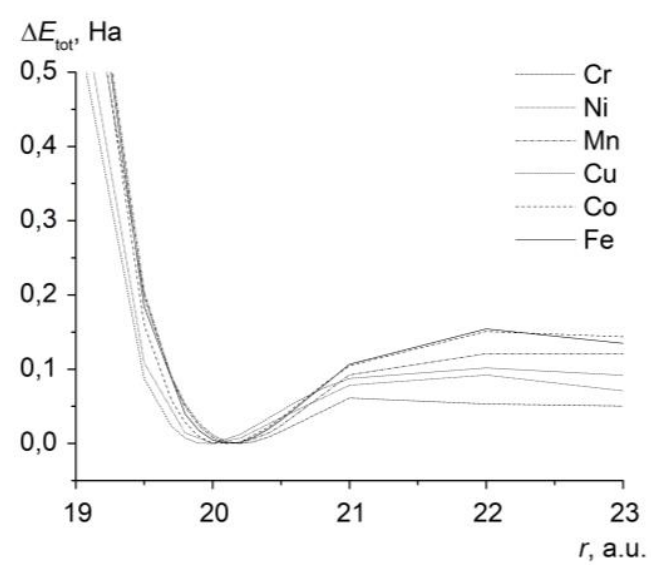

Fig. 1 - The total energy changes $\left(\Delta E_{t o t}\right)$ of 180 silicon atoms supercell containing a dipole of two edge dislocations and two impurity atoms $\mathrm{Cr}, \mathrm{Mn}, \mathrm{Fe}, \mathrm{Co}, \mathrm{Ni}, \mathrm{Cu}$ in the region of the dislocation core depending on the position of impurity atoms

An analysis of the interaction curves of impurity atoms with an edge dislocation in silicon made it possible to establish the equilibrium position of point defects. Given the features of the construction of the supercell, the equilibrium position is measured from its center. From the depth of the potential pit of the interaction curves, the binding energy of impurity atoms with an edge dislocation in silicon was determined. The values of the equilibrium position and binding energy of transition metals $\mathrm{Cr}, \mathrm{Mn}, \mathrm{Fe}, \mathrm{Co}, \mathrm{Ni}, \mathrm{Cu}$ with an edge dislocation in silicon are presented in Table 1. In [9], the first density functional calculations of substitutional copper at $90^{\circ}$ and $30^{\circ}$ partial dislocations in silicon are presented, the binding energy of a copper atom with $30^{\circ}$ and $90^{\circ}$ dislocations is 1.5 and $2 \mathrm{eV}$, respectively. Thus, the results of our calculations are in good agreement with the calculations of other authors.

It should be noted that if we continue to move impurity atoms perpendicular to the dislocation line in the region of a practically undeformed silicon lattice, a significant increase in the system energy is observed. The value of this energy for various impurity atoms of transition metals under consideration is in the range of $6-15 \mathrm{eV}$. We suppose that this is due to the fact that transition metal atoms have an atomic radius $23-27 \%$ larger than the atomic radius of a silicon atom, and also because of their placement in the "undeformed" silicon lattice without taking into account possible atomic displacements of the neighbors, which actually corresponds to an unrealizable situation. However, even without taking into account lattice distortions, the resulting energy jump of the system can be interpreted as a "rough" estimate of the energy necessary for the transition metal impurity atoms to leave the defective lattice zone. It should be noted that the exit energy of impurity atoms from the defective lattice zone is so large that we can talk about the formation of efficient traps for transition metals in these places.

It can be noted that the values of the binding energies are large enough that indicates the occurrence of additional energy barriers [1], as well as the possibility of the formation of impurity atmospheres around the dislocation cores, which is observed experimentally.
Table 1 - The binding energy and equilibrium position of transition metal impurities with dislocations in silicon

\begin{tabular}{|c|c|c|}
\hline Impurity & $\begin{array}{c}\text { Binding energy } \\
\text { (per 1 atom), eV }\end{array}$ & $\begin{array}{c}\text { Equilibrium position, } \\
\text { a.u. }\end{array}$ \\
\hline $\mathrm{Cr}$ & 0.834 & 20.2 \\
\hline $\mathrm{Mn}$ & 1.645 & 20.2 \\
\hline $\mathrm{Fe}$ & 2.098 & 20.1 \\
\hline $\mathrm{Co}$ & 2.0529 & 20.0 \\
\hline $\mathrm{Ni}$ & 1.253 & 20.0 \\
\hline $\mathrm{Cu}$ & 1.385 & 20.0 \\
\hline
\end{tabular}

It can be noted that the values of the binding energies are large enough that indicates the occurrence of additional energy barriers [1], as well as the possibility of the formation of impurity atmospheres around the dislocation cores, which is observed experimentally.

Also, in this paper, we studied the electronic structure changes of the selected supercell depending on the positions of point defects. As an example, we present the energy spectra of a silicon supercell containing a dipole of two edge dislocations and impurity atoms $\mathrm{Cr}, \mathrm{Mn}, \mathrm{Fe}$, $\mathrm{Co}, \mathrm{Ni}, \mathrm{Cu}$ near the dislocation cores in the equilibrium position (Fig. 2-Fig. 4). The Fermi level is indicated by the arrow.

For all studied transition metal impurities, the spectra of the electronic states density generally corresponds

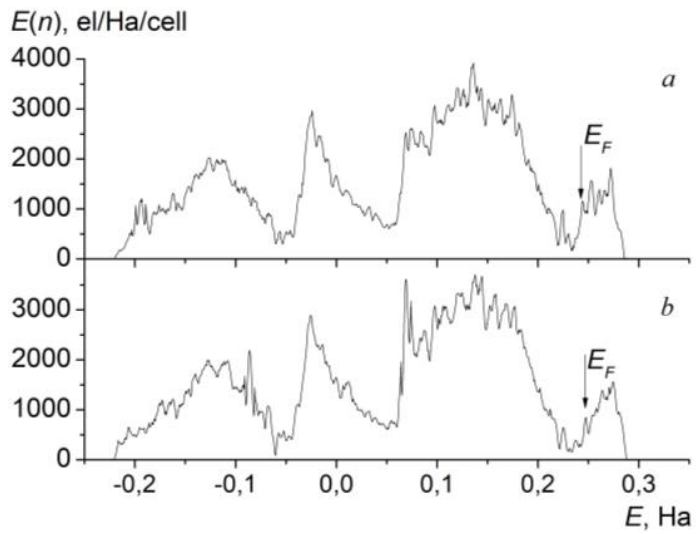

Fig. 2 - The electronic density of states of 180 silicon atoms supercell with a dislocation dipole and a transition metal impurity atom near each dislocation core: $\mathrm{a}-\mathrm{Cr}, \mathrm{b}-\mathrm{Mn}$

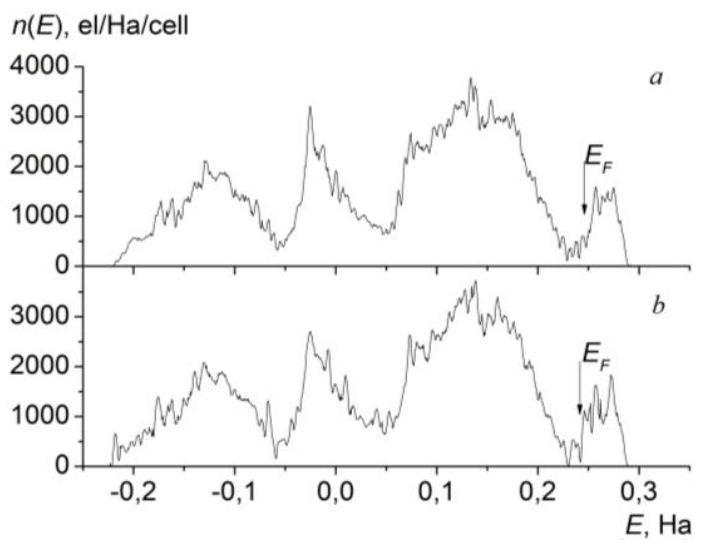

Fig. 3 - The electronic density of states of 180 silicon atoms supercell with a dislocation dipole and a transition metal impurity atom near each dislocation core: $\mathrm{a}-\mathrm{Fe}, \mathrm{b}-\mathrm{Co}$ 


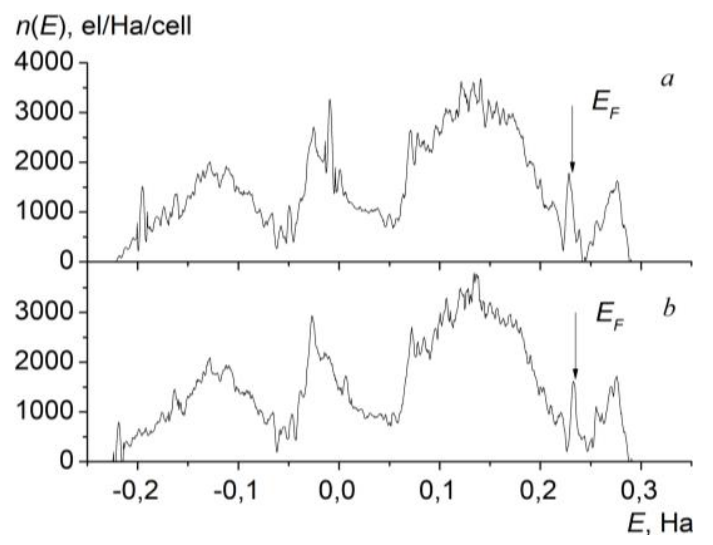

Fig. 4 - The electronic density of states of 180 silicon atoms supercell with a dislocation dipole and a transition metal impurity atom near each dislocation core: $\mathrm{a}-\mathrm{Cu}, \mathrm{b}-\mathrm{Ni}$

to the spectrum of pure Si. The general features of the electronic spectra for all impurity atoms are observed: the band gap of the investigated supercell is significantly reduced, and additional states appear in the band gap, which is typical for semiconductors and is also observed for previously studied impurities [10, 11]. Analyzing the local spectra of the electron density, these additional peaks in the band gap can be attributed to the defective structure of the selected supercell.

According to our analysis of the electronic structure of dislocation silicon with transition metal impurities, it can be concluded that the intensity and fine structure of impurity peaks vary depending on the type of impurity atom and its position.

The investigated impurities of transition metals can be divided into two groups by their effect on the electronic structure of dislocation silicon. The first group includes $\mathrm{Cr}, \mathrm{Mn}, \mathrm{Fe}$ and Co. For these impurities, additional states in the band gap are indistinct and almost merge with either the valence band or the conduction band (Fig. 2 and Fig. 3). The second group includes Ni and $\mathrm{Cu}$. For these transition metals (see Fig. 4), a sharp impurity peak appears near the Fermi level in the band gap. Moreover, in this case, the Fermi level locates almost on the center of the impurity peak.

For impurities of transition metals $\mathrm{Ni}, \mathrm{Cu}$ in 180 silicon atoms supercell with an edge dislocation, the calculated electronic spectra can be analyzed by applying the Stoner criterion, which determines the occurrence of band magnetism. According to this criterion, the presence of a semi-filled narrow subzone in the vicinity of the Fermi level is required for the magnetic ordering on the band scheme. As the obtained electron spectra show, for impurity atoms $\mathrm{Ni}, \mathrm{Cu}$ sharp impurity peaks appear in the forbidden zone of silicon due to the defective structure of the investigated supercell. Whereby the Fermi level reaches almost the maximum of these impurity peaks, i.e. these impurity peaks are semi-filled (Fig. 4). Consequently, when the impurity atoms $\mathrm{Ni}, \mathrm{Cu}$ are immersed in the region of the dislocation core in silicon, local magnetic ordering may occur. It may be an explanation of the influence of the magnetic field on the impurity subsystem in silicon, which was experimentally observed in $[12,13]$.

\section{CONCLUSIONS}

In the course of our first principles calculation of the electronic structure of a supercell of 180 silicon atoms with an edge dislocation and impurities $\mathrm{Cr}, \mathrm{Mn}$, $\mathrm{Fe}, \mathrm{Co}, \mathrm{Ni}, \mathrm{Cu}$ in the region of the dislocation core, the equilibrium position of impurities was calculated and the binding energies of impurity atoms with an edge dislocation were estimated. The electronic structure of dislocation silicon with transition metal impurities near dislocation cores was calculated and analyzed. It is established that for impurities $\mathrm{Ni}, \mathrm{Cu}$ in the vicinity of the edge dislocation, the band magnetism can appear in the places of increased concentration of defects due to the electronic structure peculiarities.

\section{REFERENCES}

1. H.J. Choi, M.I. Bertoni, J. Hofstetter, D.P. Fenning, D.M. Powell, S. Castellanos, T. Buonassisi, IEEE J. Photovoltaics 3 No 1, 189 (2013).

2. A.A. Istratov, W. Huber, E.R. Weber, J. Electrochem. Soc. 150, G244 (2003).

3. A.T. Blumenau, R. Jones, S. Oberg, P.R. Briddon, T. Frauenheim, Phys. Rev. Let. 87, 187404 (2001).

4. M. Werner, E.R. Weber, S. McHugo, H. Hieslmair, K.L. Chapman, Solid State Phenom. 47-48, 449 (1996).

5. A.A. Istratov, H. Hieslmair, E.R. Weber, Appl. Phys. A 69, 13 (1999)

6. A.A. Istratov, E.R. Weber, Appl. Phys. A 66, 123 (1998).

7. I.V. Plyushchay, O.I. Plyushchay, V.A. Makara, Metallofiz. Noveishie Tekhnol. 36 No 5, 589 (2014).

8. X. Gonzea, B. Amadond, P.-M. Anglade, J.-M. Beuken, F. Bottin, P. Boulanger, F. Bruneval, D. Caliste, R. Caracas, M. Cotŭ, T. Deutsch, L. Genovese, Ph. Ghosez, M. Giantomassi, S. Goedecker, D.R. Hamann， P. Hermet， F. Jollet， G. Jomard， S. Leroux, M. Mancini, S. Mazevet, M.J.T. Oliveira, G. Onida, Y. Pouillon, T. Rangel, G.-M. Rignanese, D. Sangalli, R. Shaltaf, M. Torrent, M.J. Verstraete, G. Zerah, J.W. Zwanziger, Comput. Phys. Com. 180, 2582 (2009).

9. N. Fujita, R. Jones, S. Oberg, P.R. Briddon, and A.T. Blumenau, Solid State Phenom. 131-133, 259 (2008).

10. T.V Gorkavenko, I.V. Plyushchay, O.I. Plyushchay, V.A. Makara, J. Nano- Electron. Phys. 9, 04025 (2017).

11. T.V. Gorkavenko, I.V. Plyushchay, O.I. Plyushchay, V.A. Makara, J. Nano- Electron. Phys. 10, 04030 (2018).

12. M.V. Badylevich, Yu.L. Iunin, V.V. Kveder, V.I. Orlov, Yu.A. Osipyan, Solid State Phenom. 95-96, 433 (2004).

13. I. Yonenaga, K. Takahashi, J. Appl. Phys. 101, 053528 (2007). 


\title{
Першопринципний розрахунок взаемодії крайової дислокації з домішковими атомами перехідних металів в кремнії
}

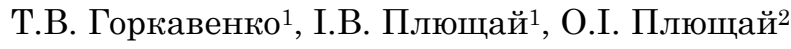 \\ 1 Київський національний університет ілені Тараса Шевченка, вул. Володимирська, 64/13, \\ 01601 Київ, Україна \\ 2 Інститут металофбізики імені Г.В. Курдюмова НАН Украӥни, бульвар. Акаделіка Вернадського, 36, \\ 03142 Київ, Україна
}

\begin{abstract}
Проведено першопринципний розрахунок взаємодії крайової дислокації з домішковими атомами перехідних металів $\mathrm{Cr}, \mathrm{Mn}, \mathrm{Fe}, \mathrm{Co}, \mathrm{Ni}$ та $\mathrm{Cu}$ поблизу ядра дислокації в надкомірці зі 180 атомів кремнію. Розрахунок проведено методом функціоналу густини в узагальненому градіентному наближенні за допомогою пакету програм ABINIT. Отримано криві взаємодії домішкових атомів з крайовою дислокаціею в кремнії. Форма кривих взаемодії відповідае потенціалу Ленарда-Джонса. Встановлено рівноважні положення домішкових атомів поблизу ядра дислокації. Обраховані та проаналізовані ене ргії зв'язку домішок $\mathrm{Cr}, \mathrm{Mn}, \mathrm{Fe}, \mathrm{Co}, \mathrm{Ni}$ та $\mathrm{Cu}$ з крайовою дислокаціею в кремнії. Отримано електронну структуру надкомірки зі 180 атомів кремнію, що містить диполь з двох крайових дислокацій та домішкові атоми $\mathrm{Cr}, \mathrm{Mn}, \mathrm{Fe}, \mathrm{Co}, \mathrm{Ni}, \mathrm{Cu}$ поблизу ядер дислокацій. Обговорені загальні особливості електронних спектрів для всіх домішкових атомів. Встановлено, що завдяки наявній дефектній структурі надкомірки з'являються додаткові стани в забороненій зоні для всіх домішок, зокрема, для домішок $\mathrm{Ni}$ i $\mathrm{Cu}$, в забороненій зоні спостерігається гострий напівзаповнений домішковий пік. Інтенсивність та тонка структура домішкових піків залежать від типу домішки та їі розташування в області дислокаційного ядра. Обговорена можливість формування магнітного впорядкування на обірваних зв'язках в ядрі крайової дислокації та перехідних металах $\mathrm{Ni}, \mathrm{Cu}$ поблизу ядра дислокацій в кремнії.
\end{abstract}

Ключові слова: Кремній, Крайова дислокація, Перехідні метали, Електронна структура, Магнітне впорядкування. 